\title{
CLINICAL SIGNIFICANCE AND MDCT ANGIOGRAPHIC PRESENTATION OF THE MESENTERIC COLLATERAL CIRCULATION OF THE COLON
}

\author{
Nikola Nedovicl, Marija Zivkovic Radojevic ${ }^{1,2}$, Neda Milosavljevic1,2, Radisa Vojinovic1,3, Jasmina Nedovic ${ }^{2}$ \\ ${ }^{1}$ University of Kragujevac, Serbia, Faculty of Medical Sciences \\ ${ }^{2}$ Center for Oncology and Radiology, Clinical Center Kragujevac, Kragujevac, Serbia \\ ${ }_{3}^{3}$ Department for Radiology, Clinical Center Kragujevac, Kragujevac, Serbia
}

\section{KLINIČKI ZNAČAJ I MDCT ANGIOGRAFSKI PRIKAZ MEZENTERIJALNE KOLATERALNE CIRKULACIJE KOLONA}

\author{
Nikola Nedovićl, Marija Živković Radojevićl,2, Neda Milosavljević1,2, Radiša Vojinovićl,3, Jasmina Nedović ${ }^{2}$ \\ ${ }^{1}$ Univerzitet u Kragujevcu, Srbija, Fakultet medicinskih nauka \\ ${ }^{2}$ Centar za onkologiju i radiologiju, Klinički centar Kragujevac, Kragujevac, Srbija \\ ${ }_{3}^{3}$ Služba za radiološku dijagnostiku, Klinički centar Kragujevac, Kragujevac, Srbija
}

\section{ABSTRACT}

Developed mesenterial collateral system provides adequate perfusion of the colon in conditions and diseases where blood flow is disabled or compromised.

MDCT angiography is the optimal method, providing an adequate review of the blood vessels in a high resolution image, which is of great importance in the diagnosis of various anatomical variations, diseases and conditions

Keywords: colon, CT angiography, mesenteric ischemia

\section{INTRODUCTION}

Mesenterial circulation owns an extremely rich network of collaterals, and the layout and configuration of these collaterals are very important during surgical interventions, which is why radiological visualisation of these collaterals, as well as its adequate interpretation have exceptional significance. The aim of this paper is the presentation clinical significance of the mesenteric collateral circulation of the colon, several aspects of compromised collateral mesenteric circulation and MDCT angiographic presentation of the mesenteric collateral circulation of the colon.

\section{EMBRYOLOGY}

The formation of the aorta begins between the $3^{\text {th }}$ and $4^{\text {th }}$ weeks of pregnancy (1), giving branches for each segment of the embryonal circulation: posterolateral, lateral and ventral branches from which the vitelline and umbilical arteries are formed (1). From the vitreous arteries, the celiac, superior and inferior mesenteric arteries develop. Vitelline arteries initially represent even blood vessels of the yolk sac, resulting from the merger and formation of dorsal mesentrium arteries of the intestine. These blood vessels vascularize the front, middle and back intestine (2). Mesenteric arteries

\section{SAŽETAK}

Dobro razvijen sistem kolaterala u predelu mezenterijuma obezbeđuje adekvatnu perfuziju abdominalnih organa, a posebno kolona i rektuma, čak i u situacijama kada je dotok krvi iz određenih krvnih sudova onemogućen ili kompromitovan.

MDCT angiografija je optimalna metoda koja obezbeđuje adekvatan pregled krvnih sudova pomoću slike visoke rezolucije, što je izuzetno značajno za postavljanje dijagnoze razlicitith anatomskih varijacija, bolesti i stanja.

Ključne reči: kolon, CT angiografija, mezenterična ishemija

originate from primitive ventral segmental arteries. Regression of these primitive blood vessels occurs, along with their development, but during this process, three blood vessels remain. These are the three main mesenteric trunks. The tenth segmental artery forms a celiac artery that vasculates the front intestine (develops into region between the esophagus and the distal duodenum). The thirteenth artery builds up the superior mesenteric artery. This artery vascularizes the middle intestine from which, later, part between the proximal part of duodenum and the middle of the transversal colon develop. The twenty-first or twenty-second artery forms the inferior mesenteric artery, which supplies blood to the back intestine (2).

\section{COLON ARTERIES}

The colon has a double vascularisation, and it consists of superior and inferior mesenteric arteries. The rectum and anal canal feed the branches of superior mesenteric artery and internal iliac artery. This type of vascularisation provides adequate circulation to this metabolically extremely active region, but in case of malignant and other colorectal diseases, affects the course and outcome of them. Vascular anatomy of colon and rectum influence the extent and radicality of surgical intervention of the colorectal region, and in particular the extent of lymphadenectomy (3). 


\section{COLLATERAL SUPPLY OF COLON AND RECTUM}

A well-developed collateral system in the mesenteric area provides adequate perfusion of the abdominal organs, especially the colon and rectum, important in situations where blood flow from certain blood vessels is disabled or compromised. Colon and rectum can be preserved when the main mesenteric branches are surgically ligated during colorectal carcinoma surgery, or are significantly stenosed during advanced atherosclerotic processes. In chronic ischemia, the occurrence of symptoms is long and in this situation, angiography of mesenteric circulation is a sovereign method for assessing the condition of the vasculature of the colon (4). These blood vessels, in presence of ischemic stimulus, have the ability to significantly increase their capacity. This characteristic is important during the diagnostic procedures, because under normal conditions, angiographic visualisation of mesenteric blood vessels is not always adequate (4).

Collateral arterial network of colon and rectum consists of:

- Celiac artery and superior mesenteric artery,

- Superior and inferior mesenteric arteries,

- Branch of the internal iliac artery and inferior mesenteric artery,

- Visceral and parietal branches of the aorta,

- Superior mesenteric artery and hepatic artery, where the middle colic artery arises from the hepatic artery,

- Anastomosis between the middle colic artery and pancreatic artery, in which case middle colic branch of superior mesenteric artery is usually missing $(5,6)$.

\section{Collateral circulation between the superior and inferior mesenteric artery}

The most important collateral network, especially in oncologic surgery, is between the superior and inferior mesenteric arteries. The main collateral network between these two are:

- Drummond's marginal artery. The central anastomotic artery that connects all arterial branches of the colon was first described by Haller in 1786, but later this artery became known as Drummond's marginal artery when in 1913 he demonstrated its surgical significance (2, 8 ). The diameter of the marginal artery progressively decreases from the ascendent to the descending colon (from $1.16 \mathrm{~mm}$ to $0.89 \mathrm{~mm}$ ). The diameter itself also can vary over the years and in about $40 \%$ of cases, there are constrictions or interruptions in splenic flexure $(9,10)$. Also, when mesenteric ischemia develops, the diameter of the Drummond's artery can be increased several times, similar to the blood vessels of the uterus (11). Significant points for ischemic process development:
- Griffith's point, located near the splenic flexure of colon, at the point where branches of the middle and left colic arteries are encountered. Ischemic changes occur in $5-7 \%$ of cases, due to reduced arterial diameter and absence of collateral vessels (lat. Vasa recta) (12). Griffith's point, may also be missing, in about $50 \%$ of cases (13).

- Sudeck's point. Named after Sudeck, in 1907. It is located on the juncture of collateral blood vessels of systemic and visceral circulation (9), or between the lower part of the sigmoid colon and the upper hemorrhoidal artery (13).

- Middle, right colic and ileocolic arteries build anastomosis network in the form of a colon marginal artery, which is completed only when it forms anastomosis via the left arterial artery with inferior mesenteric artery (14).

- Riolan's arcade located in the mesenterium, allowing communication between the middle and left colic arteries or inferior mesenterial artery. This arcade can only be found in $7-10 \%$ of the population (9). In case of colon obstruction, its diameter increases several times.

- Moscowitz's curved artery presents connection between the proximal segment of the middle colic artery and ascedent branch of left colic artery, following base of colon mesenterium.

\section{Clinical conditions with compromised collateral mesenteric circulation}

There are several clinical entities that require increased blood flow to the colon via the collateral blood vessels network:

Changes in the colon caused by the aging. These changes are associated with changes in other blood vessels of the whole organism. They are especially rapidly advancing when there is an associated disease in the form of chronic heart disease, long-term and untreated hypertension, advanced atherosclerotic processes. Also, hypotensive episodes can cause ischemic colitis, in older people, when they are far more severe than in younger people (10). In young people, blood vessels are straight and with little curvature. The curvature of the short blood vessels increases in proportion to aging. At the same time, there was no statistically significant difference between the curvature of long colic arteries in different colon segments. The number of long arteries per unit of colon length does not change with age (10).

Abdominal angina. This is a condition that arises as a result of a reduction in blood flow to at least two of the three blood vessels, superior mesenteric artery, inferior mesenteric artery and celiac artery that supply the splanhic region. Whether there will abdominal angina attack 
appear, depends on the strength of the collateral circulation to bear the ischemic burden (6).

Ischemic colitis. It represents the consequence of mesenterial arterio-venous malformation (15). They most commonly occur in the area of superior and inferior mesenteric arteries branching (Griffith's point). This is also the case with the elderly, with peak incidence in the seventh decade (16) and manifests inone of two forms, depending on the extent and duration of vascular lesion, the effectiveness of collateral circulation, and the severity of secondary bacterial infection (17-20):

1. Gangrenous ischemic colitis is an infarction consequence of all layers of the bowel wall and infection. Perforations with peritonitis with high mortality are common. Treatment outcome depends on rapid and energetic preoperative reanimation and surgery resection of the affected part of the colon with or without primary anastomosis, depending on the conditions. Unfortunately, patient's general condition and the local finding mainly allow only exteorisation as a surgical solution $(10,17)$.

2. Stenosing ischemic colitis (ischemic stenosis) is a consequence of extensive damage of arterial circulation in the bowel wall, resulting in numerous infarctions in the mucous membrane of the affected segment of the intestine with ulceration that open the pathway to infection (20).

Non-occlusive mesenteric ischemia. This type of mesenteric ischemia increases arterial curvature and probably, causes ischemia of mucosis, when resistance to blood flow increases. When blood flows through the curve, the secondary flow is due to a centrifugal force that is associated with blood flow in the curve. The combination of primary and secondary blood flow provides double helix blood movement and pressure increase, which causes an increase in blood flow that does not depend on previous movement (21). In people with higher blood vessels curvature, weaker circulation in the splanchnic region is observed, which increases the chance for developing an ischemic colitis. At places where there is vessels curvature, there is a significant wall thickness, elastosis and wall stratification, hypertrophy and calcification. Left side of colon is more often affected with ischemic colitis than the right side of colon (10).

Ischemic colitis associated with colorectal cancer. This condition can be manifested by a dramatic clinical picture caused by the onset of necrosis or perforation of the rectal wall, as a consequence of severe vascular failure. Different degrees of ischemic changes can be recognized, during surgery, as inserted part of the ischemic colon, which leads to the anastomosis leak. Ischemic colitis can be overlooked during colonoscopic examination, so a colon biopsy needs to be performed to establish an accurate diagnosis (22).
Radical surgical treatment of colorectal cancer. This treatment involves the removal of the primary tumor and the resection of a significant part of the healthy bowel, over $5 \mathrm{~cm}$ from the macroscopic tumor margins, as well as all lymph nodes and pathways belonging to a particular colon segment. In the case of tumors invasion in abdominal wall and adjacent organs, a wide block excision is recommended. The surgical technique involves bridging the lumen of the colon, as well as the arterial and venous pathways ligature that drain affected bowel segment, significantly reducing possibility of disseminating malignant cells during the operation (23).

Unconventional cases of mesenteric ischemia. Both acute and chronic mesenteric ischemia can cause severe consequences for the patient. Both cases lead to high mortality rate. Arteries atherosclerotic changes of the splanhic region often coexist with acute embolization and non-occlusive mesenteric ischemia. The cause of death may be irreversible shock onset or intestine necrosis. For these reasons it is important to recognize the unusual manifestation of the disease at the earliest stage. Unusual cases of intestinal ischemia can be classified into six groups. These are mechanical, drug induced, hematological, endocrine, caused by diseases of the blood vessels and various others. Each of these categories must be thought of in everyday work (24).

Operations on the left colon. During left colon operative maneuver, whenever is possible large mesenteric resections should be avoided $(23,25)$. When there is a flow in the direction from superior to inferior mesenteric artery, associated with necrosis or bloodstream insufficiency of the sigma or rectum at the, lower limb ischemia may occur.

\section{MDCT angiography in the visualisation of mesenteric collateral circulation in various clinical entities}

Diagnostic procedures, carried out to assess the condition and configuration of collateral blood vessels, are conventional angiography, selective angiography, computed tomography (CT) and multidetector computed tomography angiography (MDCTA).

For the evaluation of splanchnic circulation, the optimal method is MDCTA, with subsequent multiplanar reconstructions (MPR). For examination of superior and inferior mesenteric artery, proximal parts of the celiac, 3D display is not necessary to use. In contrast, the distal parts of these arteries are best visualized using the 3D image display software (26).

Today, MDCTA is the first-choice method, providing an overview of the arterial hypertrophy in a high resolution image, which is of great importance in the diagnosis of various anatomical variations, diseases and 
conditions $(27,28)$. Using MDCTA, changes in arteries is possible to visualize, which in $66 \%$ of cases are not visible on CT or conventional angiography (29). Identification of this characteristics using MDCT angiography can very often be of significance during the diagnosis of conditions requiring surgical intervention $(30,31)$. Anatomical variation, using this method, can be detected in almost $100 \%$ of cases (32).

Due to non-specific abdominal symptoms, it is difficult to diagnose mesenteric ischemia. The first symptom is usually abdominal pain (33). Occlusion of mesenteric arteries is characterized by slow progression and non-specific clinical features, unlike venous occlusion (34). MDCTA represents the gold standard in the diagnosis of this condition (35). Secondary signs indicating acute mesenteric occlusion are: wall thinning of the intestine, slow recovery and free fluid infusion (36). In case of complete obstruction of these arteries, vascularisation may be optimal due to the existence of a collateral network. In case of complete obstruction in the lumen, these collaterals are not visualized in all cases (37).

Acute mesenteric ischemia presents an urgent, lifethreatening condition with a high mortality rate $(26,38)$. Compared to conventional, CT angiography, MDCT angiography performance significantly improved, because of rapid volumetric data acquisition. By using MDCTA, cause of bowel ischemia and location, as well as the presence of mesenteric blood vessels or mesenterium wall abnormalities can be detected. The cause can be arterial or venous occlusion, hypoperfusion in vascular nonocclusive diseases or strangulation $(26,38-42,43)$.

Chronic mesenteric ischemia can often be manifested with abdominal pain. In most cases, it is a consequence of atherosclerosis (44). It is more common in patients treated for liver disease, gall bladder or pancreas diseases (45).

The protocol of mesenterial circulation examination includes three phases MDCT: without contrast (native series), arterial and port (venous) phase. The MDCT parameters are given in Table 1.

Table 1. MDCT parameters

\begin{tabular}{|c|c|}
\hline Detector configuration & $64 \times 0.625 \mathrm{~mm}$ \\
\hline Tube voltage & $120 \mathrm{kVp}$ \\
\hline Tube current & $100-400 \mathrm{mAs}$ \\
\hline Slice thickness & $0.5 \mathrm{~mm}$ \\
\hline Reconstruction interval & $0.4-0.8 \mathrm{~mm}$ \\
\hline Pitch & $0.828 \mathrm{~mm}$ \\
\hline Rotation time & $0.5 \mathrm{sec}$ \\
\hline
\end{tabular}

Before examination, patient does not use oral contrast. Subsequently, after the native series, through the cubital vein $100-125 \mathrm{ml}$ iodine, non ionic contrast material, is administered using an automatic injector. The concentration of iodine in contrast must be equal to or greater than $300 \mathrm{mg}$ per $\mathrm{ml}$, and the administration rate at least $4 \mathrm{ml}$ per second or faster. The arterial phase begins when automatic measurements achieve a density of 150 Hounsfield Units (HU) in the proximal part of the abdominal aorta. The port phase starts after 40-60 seconds, or 70-90 seconds from the beginning of intravenous contrast administration $(35,46)$.

In $3 \mathrm{D}$ imaging of abdominal structures and/or blood vessels, two methods are used: Maximum intensity projection (MIP) imaging and volume rendering (VR). MIP accentuates higher density voxels (arteries and veins with contrast) in comparison to surrounding structures, summarizing them in 3D formations. In this way, blood vessels are filled with contrast at a certain stage. VR uses a complex software algorithm and allows reproducing structures of different densities in 3D in a more effective way than the MIP. The application of both methods for 3D visualisation of blood vessels involves the use of special workstations for post-processing of examinations $(35,45-$ 46).

\section{CONCLUSION}

MDCTA, as a non-invasive technique for examination blood vessels in general, is a gold standard in the visualisation of mesenteric collateral circulation, both in different clinical states that require this diagnostic, and in the detection of anatomical varieties of arteries and veins of this region.

Conflict of interest statement: The authors declare that there is no conflict of interest related to this study.

\section{ABBREVIATIONS}

CT - computed tomography

HU - Hounsfield Units

MDCTA - multidetector computed tomography angiography

MIP - maximum intensity projection

MPR - multiplanar reconstructions

VR - volume rendering

\section{LITERATURE}

1. Dudek RW. High- Yield Embryology. $2^{\text {nd }}$ edition. Lippencott Williams \& Wilkins, Philadelphia, 2001; 31-6. 
2. Sadler TW. Langman's Medical Embryology. $12^{\text {th }}$ edition. Philadelphia: Wolters Kluwer Health/Lippincott Williams \& Wilkins, 2012; 259.

3. Kornblith PL, Boley SJ,Whitehouse BS. Anatomy of the splanchnic circulation. Surgical Clinics of North America 1992; 72: 1-30.

4. Zollinger RM, Ellison EC. Zollinger's atlas of surgical operations. $9^{\text {th }}$ edition. 2011; 132.

5. Michels N, Siddarth P, Kornblith P. The variant blood supply to the small and large intestines: Its importance in regional resections. Journal International College of the Surgeons 1963; 39: 127-33.

6. Yíldílrím M, Çelik HH,Yíldíz Y. et al. The middle colic artery originating from the coeliac trunk. Folia Morphol 2004; 63: 363-5.

7. Staskiewicz G, Czekajska-Chehab E, Uhlig S et al. From artery of Adamkiewicz to circle of Willis: eponyms in cardiac and vascular radiology. European Society of Radiology 2011.

8. Drummond H. Some points relating to the surgical anatomy of the arterial supply of the large intestine. Proc R Soc Med 1914; 185- 97.

9. Gordon P, Nivatvongs P. Principals and Practice of Surgery for the Colon, Rectum and Anus. $30^{\text {th }}$ edition. 2007; 15-9.

10. Binns JS, Isaacson P. Age-related changes in the colonic blood supply: their relevance to ischemic colitis. Gut 1978; 19: 384-90.

11. Tank PW. Grant's dissector. $13^{\text {th }}$ edition. Baltimore: 2005; 84-6.

12. Sinelikov RD. Atlas of human anatomy in tree volumes. Volume II part 2. The science of the Viscera and Vessels. Moskow 1989; 308-27.

13. Beck ED, Roberts LP, Theodore J. The ASCRS Textbook of Colon and Rectal Surgery: 2nd Edition. New York: 2011; 16-7.

14. Pai SR, Prabhu V, Padmalatha N. Clinical Anatomy. Anatomica Karnataka: 2005; 40-2.

15. Poullos PD, Thompson AC, Holz G, Edelman LA, Jeffrey RB. Ischemic Colitis Due to a Mesenteric Arteriovenous Malformation in a Patient with a Connective Tissue Disorder. J Radiol Case Rep 2014; 8: 9-21.

16. Sotiriadis J, Brandt LJ, Behin DS, Southern WN. Ischemic colitis has a worse prognosis when isolated to the right side of the colon. Am J Gastroenterol 2007; 102: 2247-52.

17. Scowcroft CW, Sanowski RA, Kozarek RA. Colonoscopy in ischemic colitis. Gastrointest Endosc 1981; 27: 156-61.
18. Brandt LJ, Boley SJ. Colonic ischemia. Surg Clin North Am 1992; 72: 203-30.

19. Gore RM, Yaghmai V, Thakrar KH et al. Imaging in intestinal ischemic disorders. Radiol Clin North Am 2008; 46: 845-75.

20. Chang HJ, Chung CW, Ko KH, Kim JW. Clinical characteristics of ischemic colitis according to location. J Korean Soc Coloproctol 2011; 27: 282-6.

21. Brech R, Bellhouse BJ. Flow in branching vessels. Cardiovasc Res 1973; 7: 593-600.

22. Seow-Choen F, Chua TL, Goh HS. Ischemic colitis and colorectal cancer: some problems and pitfalls. Int J Colorectal Dis 1993; 8: 210-2.

23. Gerzić Z et al. Osnovi hirurgije. Beograd. 1994; 135589.

24. Krupski WC, Selzman CH, Whitehill TA. Unusual causes of mesenteric ischemia. Surg Clin North Am 1997; 77: 471-502.

25. Kornblith PL, Boley SJ. Whitehouse BS. Anatomy of the splanchnic circulation. Surg Clin North Am 1992; 72: $1-30$.

26. Horton KM, Fishman EK. Multidetector row and 3D $\mathrm{CT}$ of the mesenteric vasculature: normal anatomy and pathology. Semin Ultrasound CT MR 2003; 24: 35363.

27. Soyer P, Bluemke DA, Bliss DF, Woodhouse CE, Fishman EK. Surgical segmental anatomy of the liver: demonstration with spiral CT during arterial portography and multiplanar reconstruction. AJR Am J Roentgenol 1994; 163: 99-103.

28. Cazejust J, Bessoud B, Colignon N, Garcia-Alba C, PlanchéO, Menu Y. Hepatocellular carcinoma vascularisation: from the most common to the lesser known arteries. Diagn Interv Imaging 2014; 95: 27-36.

29. Chen JK, Johnson PT, Horton KM, Fishman EK. Unsuspected mesenteric arterial abnormality: comparison of MDCT axialsections to interactive 3D rendering. AJR Am J Roentgenol 2007; 189: 807-13.

30. Duffy AJ, Panait L, Eisenberg D, Bell RL, Roberts KE, Sumpio B. Management of median arcuate ligament syndrome: a newparadigm. Ann Vasc Surg 2009; 23: 778-84.

31. Cazejust J, Garcia-Alba C, Colignon N, Planché O, ElMouhadi S, Menu Y. Chemoembolization and the arcuateligament: how to manage it? Diagn Interv Imaging 2014.

32. El-Hayek KM, Titus J, Bui A, Mastracci T, Kroh M. Laparoscopic median arcuate ligament release: are we improving symptoms? J Am Coll Surg 2013; 216: 272-9. 
33. Romano S, Lassandro F, Scaglione M, Romano L, Rotondo A, Grassi R. Ischemia and infarction of the small bowel and colon: spectrum of imaging findings. Abdom Imaging 2006; 31: 277-92.

34. Reginelli A, Iacobellis F, Berritto D, Gagliardi G, Di Grezia G, Rossi $M$ et al. Mesenteric ischemia: the importance of differential diagnosis for the surgeon. BMC Surg 2013; 13: S51.

35. Artigas JM, Martí M, Soto JA, Esteban H, Pinilla I, Guillén E. Multidetector CT angiogra-phy for acute gastrointesti $\neg$ nal bleeding: technique and findings. Radiographics 2013; 33: 1453-70.

36. Schieda N, Fasih N, Shabana W. Triphasic CT in the diagnosis of acute mesenteric ischemia. Eur Radiol 2013; 23: 1891-900.

37. Delabrousse E, Ferreira F,Badet N, Martin M,Zins M. Copingwith the problems of diagnosis of acute colitis. Diagn Interv Imaging 2013; 94: 793-804.

38. Hazirolan T, Metin Y, Karaosmanoglu AD et al. Mesenteric arterial variations detected at MDCT angiography of abdominal aorta. AJR Am J Roentgenol 2009; 192: 1097-102.

39. Ugurel MS, Battal B, Bozlar U et al. Anatomical variations of hepatic arterial system, coeliac trunk and renal arteries: an analysis with multidetector CT angiography. Br J Radiol 2010; 83: 661-7.
40. Rogalla P, Kloeters C, Hein PA. CT technology overview: 64-sliceand beyond. Radiol Clin North Am 2009; 47: 1-11.

41. Duchat F, Soyer P, Boudiaf M et al. Multi-detector row CT of patients with acuteintestinal bleeding: a new perspective using multiplanar and MIP reformations from submillimeter isotropic voxels. Abdom Imaging 2010; 35: 296-305.

42. Nino-Murcia M, Jeffrey Jr RB, Beaulieu CF, Li KC, Rubin GD. Multidetector CT of the pancreas and bile duct system: value of curved planar reformations. AJR Am J Roentgenol 2001; 176: 689-93.

43. Henes FO, Pickhardt PJ, Herzyk A et al. CT angiography in the setting of acute mesenteric ischemia: prevalence of ischemic and alternative diagnoses. Abdom Radiol 2017; 42: 1152-61.

44. Shaw RS, Green TH Jr. Massive mesenteric infarction following inferior mesenteric-artery ligation in resection of the colon for carcinoma. N Engl J Med 1953; 248: 890-1.

45. Gibbons CP, Roberts DE. Endovascular treatment of chronic arterial mesenteric ischemia: a changing perspective? Semin Vasc Surg 2010; 23: 47-53.

46. Raman SP, Horton KM, Fishman EK. MDCT and CT angiography evaluation of rectal bleeding: the role of volume visualisation. AJR 2013; 201: 589 - 97. 